\title{
Chapter 4 Tourism in protected areas and the transformation of Mljet island, Croatia
}

Ivan Šulc

\section{Abstract}

Located in southern Dalmatia, Mljet has some of the best-preserved nature among the inhabited Adriatic islands, and the western part was declared a national park in 1960. After World War II, the island faced intensive depopulation and transformation from an agriculture-oriented economy to a service-oriented economy. This chapter investigates the role of tourism in the socio-economic transformation of the island and the social pressure of tourism on the small local community. The goals were to investigate the role of tourism in demographic processes on Mljet, its impact on the socio-economic development of the island, and to measure the pressure of tourism on the local community. The research confirmed the significant role of tourism in the island's socio-economic and demographic transformation, but it also revealed some of the highest levels of social pressure due to tourism in southern Dalmatia, which is not acceptable for a tourism area with a highly-preserved natural environment.

Key words: protected area, nature-based tourism, coastal tourism, depopulation, social pressure of tourism, islands, geography, Mljet, Croatia 


\section{Introduction}

Coastal regions in the Mediterranean have experienced very intensive tourism development since the end of World War II, which has been even more amplified on islands (Bramwell, 2003). Rapid development of coastal tourism, based on attracting broad masses of tourists, is associated with strong expansion of hotels and other accommodation capacities (often of lower quality) (Ioannides, 2001; Andriotis, 2006; Chapman and Speake, 2011). Tourism gives an impulse to the economic development of local communities that otherwise would not have any development opportunities outside of agriculture, but has also caused large changes in coastal landscapes and the transformation of rural settlements into urbanised tourism areas (Andriotis, 2006).

Unfortunately, unplanned tourism development in some areas has generated negative environmental, socio-cultural, and economic impacts, and deteriorated the perceived attractiveness of destinations for potential tourists, who have started choosing less-transformed areas (Ioannides, 2001; Andriotis, 2006; Pulina and Biagi, 2006; Garay and Cànoves, 2011). In areas with high physical and social pressure of tourism, a part of the population has also started to feel the negative aspects of tourism, especially on the part of the population that is not directly involved in tourism (Doxey, 1975; Butler, 1980; Black, 1996; Bramwell, 2003). Bossevain and Theuma (1998) associate such negative attitudes with the development of "quality" tourism products that rapidly consume scarce natural resources, due to large infrastructural requirements (e.g. upscale hotels, marinas, golf courts) and demands for large amounts of land and natural resources. However, Zhong et al. (2008) showed, in the case of Zhangjiajie National Park in China, that negative impacts of tourism are not confined only to coastal areasthey can also affect natural areas on the mainland. Furthermore, the case of Plitvice Lakes, the national park the most threatened by over-tourism in Croatia, speaks in favour of the aforementioned theses.

The course and characteristics of tourism development in Croatia has largely followed the trends in the broader Mediterranean area, with one major difference: development took place under two different socio-economic systems (socialist and capitalist) and was completely halted by the Croatian War of Independence (1991-1995) (See: Šulc, 2017). Furthermore, tourism urbanisation has been dominated by new construction or reconstruction of private houses with apartments and rooms available for rent to tourists, while there were relatively few hotels (Šulc, 2016; 2019). These processes 
spread from the mainland to the islands later, and caused severe transformations in some small island communities (See: Starc, 2001; Faričić et al., 2010; Šulc and Zlatić, 2014; Šulc, 2016). Only protected areas in the coastal zone, with stricter regulation regimes, remained partially spared from unplanned and chaotic tourism construction. At the same time, most islands experienced highly negative demographic processes (Nejašmić, 1992; Lajić, 2006; Lajić and Mišetić, 2006; Nejašmić and Mišetić, 2006), which have only recently begun to show signs of improvement.

This chapter, therefore, investigates to what extent tourism has contributed to demographic changes and socio-economic processes on Croatian islands, using the case of Mljet, a medium-sized Adriatic island with a highly-preserved natural environment and a small population. Goals of the chapter are: (1) to investigate the role of tourism in demographic processes on Mljet; (2) to determine the impact of tourism on the socio-economic development of the island; and (3) to measure the intensity of the pressure of tourism on the local community.

\section{Research methods}

The research is based on "desk" methods that involve the analysis of data on tourism, population, and vital events. Statistical data on tourism consist of the number and structure of tourist arrivals, overnight stays (from 1966 to 2016), and tourist beds (from 1976 to 2016). Data was not analysed on a yearly basis, rather every fifth year was compared. Data was used in its original form to analyse tourism development and as combined indicators to estimate the social pressure of tourism-tourism function index (number of tourist beds per 100 inhabitants) and tourism intensity (number of tourist arrivals per 100 inhabitants).

The analysis of demographic processes used census data from the 1961-2011 period, consisting of population size, migration features, age-sex composition, education, economic activity, sector of activity, and agricultural population. Despite the changes in the methodology of censuses (censuses from 1961, 1971, 1981, and 1991 used de jure methodology and the 2001 and 2011 censuses used place of usual residence), the minor discrepancy in the population stemming from different methodologies is irrelevant for the purposes of this research and data was used in its original form. It is important to note that data on sector of economic activity was not available for 1981 , as well as data on agricultural population for 2011, which is no longer registered in censuses. 
Census data were used in the analysis of the demographic and socio-economic transformation of Mljet as absolute numbers (number of inhabitants), the share of certain segments of the population relevant for the analysis, or as relative indicators (education index, activity rate etc.). Classifications (percentage) of the population according to population composition are:

(1) age composition-young (o-14 years), adult (15-64 years), and elderly population (aged $65+$ );

(2) migration features-population that has always lived in the same settlement and population that moved from other settlements in the same municipality, other municipalities, other counties, or from abroad;

(3) educational composition-population without primary education $\left(<E_{I}\right)$, with primary education (elementary school; $\left.E_{I}\right)$, with secondary education (high school; $E_{I I}$ ), and with tertiary education (two-year study or more; $E_{I I I}$ );

(4) composition by economic activity-active, dependent, and population with income; and

(5) composition of the active population by sector of activity-primary, secondary, and tertiary sectors.

The active population consisted of employed persons, active farmers, and unemployed persons; the population with income consisted of retired persons and those with other sources of income; while the dependent population included all other economically inactive persons (See: Nejašmić, 2005). Primary sector activities comprised economic activities (agriculture, forestry, and fishing) of group A according to the Statistical Classification of Economic Activities, the secondary sector included groups $\mathrm{B}-\mathrm{E}^{\mathrm{I}}$, and the tertiary sector groups $\mathrm{F}-\mathrm{U}^{2}$ (CBS, 2007a). The analysis was based on the following combined indicators: (1) index of total population change; (2) age in-

1 Secondary economic activities are: B) mining and extraction; C) manufacturing industries; D) supply of electric energy, gas, steam and air conditioning; E) water supply, waste water treatment, waste management, and environmental sanation; and F) construction (CBS, 2007a).

2 Tertiary economic activities are: $\mathrm{G}$ ) retail and wholesale, repair of motor vehicles; $\mathrm{H}$ ) transport and storage; I) accommodation and catering services; J) information and communication; K) financial and insurance services; L) real estate affairs; M) professional, scientific, and technical activities; N) administrative and support services; O) public administration and defence, obligatory social security; P) education; Q) health services and social care; R) education, entertainment, and recreation; S) 
dex-number of elderly per 100 young inhabitants; (3) old age coefficientnumber of elderly per 100 adult inhabitants; (4) average age; (5) educational index (calculated according to the formula $E_{I}=E_{I I} \cdot E_{I I I} /<E_{I}$ ); (6) activity rate (of the total population)-share of active inhabitants in the total population; and (7) labour force participation rate-share of active inhabitants in the adult population (aged 15-64) (See: Nejašmić, 2005).

The demographic analysis also used the number of live births and deaths in the settlement from the vital statistics in the 1964-2011 period. As data was used as absolute numbers in ten-year census periods, the number of vital events in the 1961-1971 period was estimated using the seven-year average in the 1964-1970 period. These data were used to calculate the natural increase and net migration in ten-year census periods, by subtracting the natural increase from the total population change.

\section{Tourism on the island Mljet}

With a surface area of $99.3 \mathrm{~km}^{2}$, the island Mljet extends $37 \mathrm{~km}$ in a northwest-southeast direction and has a maximum width of $3 \mathrm{~km}$. In 1960, the western part of the island was declared a protected area (Mljet National Park), due to its highly indented coast with two connected bays (called the Big Lake and the Small Lake), numerous islands and specific marine geomorphological forms, as well as preserved natural vegetation consisting of Aleppo pine, Holm oak, and macchie. Around $70 \%$ of the island is covered by autochthonous forests, representing one best-preserved environments found among Adriatic islands. The island is administratively governed by the Municipality of Mljet and has 14 settlements-three within Mljet National Park (Goveđari, Polače, Pomena), five located in the island's interior (Babino Polje, Blato, Korita, Maranovići, Prožura), and six on the coast (Kozarica, Okuklje, Prožurska Luka, Ropa, Saplunara, Sobra). This chapter focuses on the period of the 1960 s to the time of writing, which has been marked by intensive socio-economic processes and tourism development.

Tourism on the island Mljet started to develop quite late compared to other destinations in southern Dalmatia, due to poor transport connections and isolation. The first tourists visited the western part of the island in 1924 and the first accommodation facility opened next to the Big Lake in 1934 (Šubić, 1995; Pansion Jezero, 2015). World War II seriously interrupted tourism development, which took almost a decade to recover (Šulc,

other services; T) activities of households as employers and for the needs of personal households; $\mathrm{U}$ ) activities of extra-terrritorial organisations and bodies (CBS, 2007a). 
2017). In the mid-1950s, residents in Goveđari, a settlement located next to the lakes, started to rent rooms in their houses to tourists but only few domestic tourists were visiting the island at the time (Šubić, 1995). The turning point in tourism development was the establishment of Mljet National Park in 1960, the construction of the first hotel on St. Mary's Island in the Great Lake, and the construction of communal infrastructure (Šubić, 1995; Šulc, 2017). Tourists were attracted by preserved and protected nature, associated with opportunities for a "sun and sea" holiday. Most of them would come in summer and stay within the Park; though the island was spared from mass tourism (in 1966 it recorded 1,603 tourist arrivals and 15,985 overnight stays, all in Mljet National Park) (Tab. 1).

In the 1970s, overnight tourism started to develop extensively outside the Park in the small coastal settlements Sobra and Okuklje, but it was limited to a few private households (Šulc, 2017). In 1978, Hotel Odisej (with 400 beds) was built in Pomena, the entry port to the National Park, which is the largest project on the island to date (Šulc, 2017). Increases in accommodation capacity were not followed by a cooresponding increase in the number of beds, due to inconsistent registration, but it resulted in rapid increases in tourism. In 1986, the pre-war peak year, the island registered 11,086 arrivals and 85,718 overnight stays, almost all in the Park (Tab. 1). The tourism supply remained unchanged and based on the "sun and sea" concept in highly-preserved natural area, with a rather long average stay of 7.7 nights. The Park is also a favourite destination for day-trippers from Dubrovnik, Pelješac Peninsula, and the nearby islands Hvar and Korčula (Šulc, 2017).

In the late 1980s, tourism started to show the first signs of crisis (Šulc, 2017) and it completely declined when the War started in the early 1990 os. New tourism growth was initiated by the re-opening of the Hotel Odisej in 1993 and continued to increase up to 2006, when the island reached its pre-war level of visitation (14,707 arrivals and 70,036 overnight stays). In the meantime, the other hotel closed and more residents got involved with tourism by renting apartments in their households. Consequently, in 2006, the share of the Park in all tourist beds decreased to $48 \%$, while coastal settlements reached $40 \%$ and interior settlements $12 \%$ (Tab. 1). Although the structure and travel habits of tourists changed, spending summer holidays in a preserved natural environment remained the most important motivation for visitors, due to which the Park still registered $75 \%$ of all tourists on the island. 
Tab. I Tourist arrivals, overnight stays, and tourist beds on Mljet in the 1966-2016 period, by groups of settlements

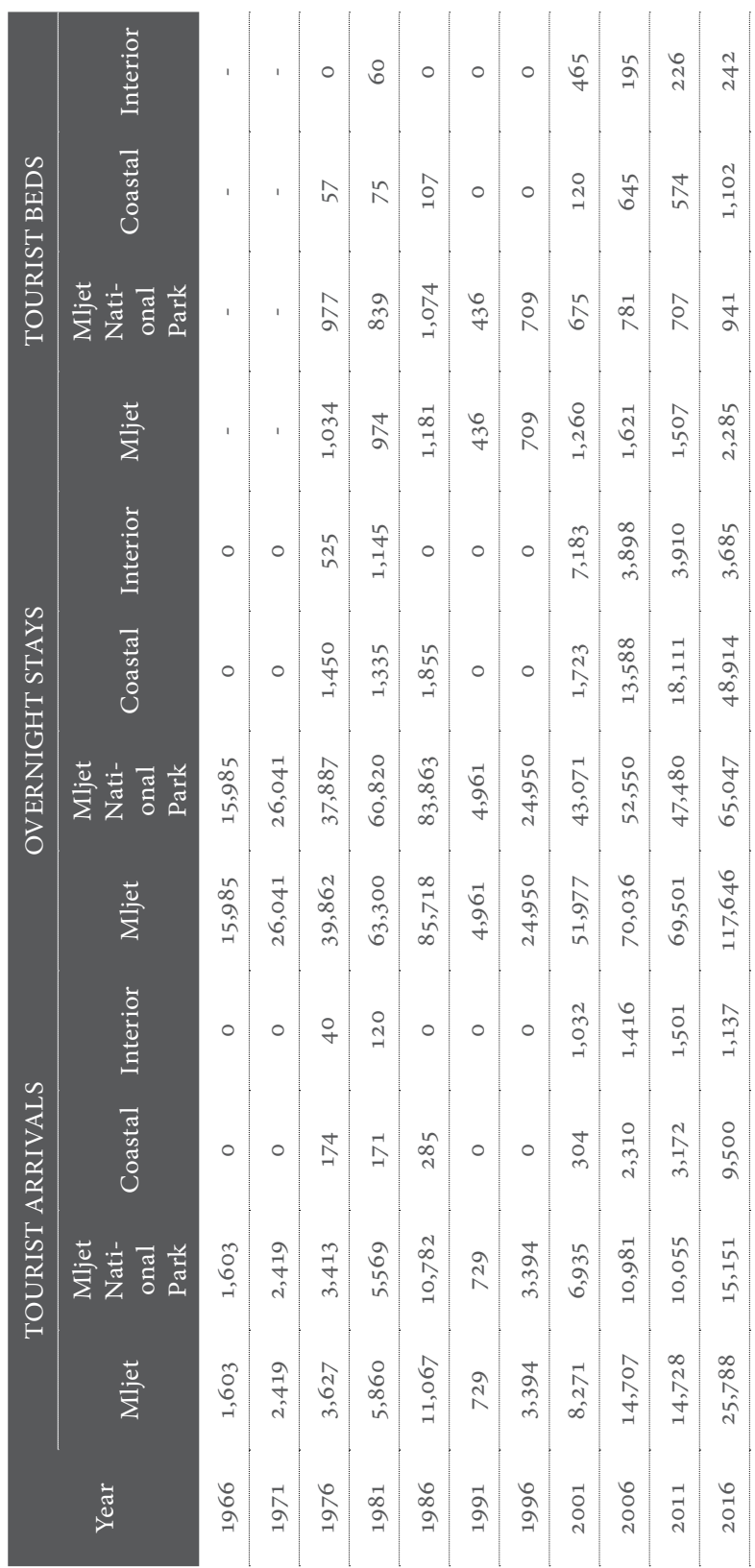

Sources: RBS (1967; 1972; 1977; 1982; 1987); CBS (1992; 1997; 2002; 2007b; 2012; 2017) 
The period of stagnation that followed in the late 2000 s was generated by the economic crisis on the main international tourist markets, the island's underdeveloped and stagnant tourism supply, and the fickle nature of tourists' preferences (Šulc, 2017). Concurrently, almost all settlements became involved in tourism by offering similar tourism products. Economic recovery after 2011 and improvements in the tourism supply in Croatia managed to stimulate new and intensive tourism growth, which was, on Mljet, connected with rather high increases in private accommodation in coastal settlements (particularly Saplunara and Sobra) and in the Park, but less in interior settlements (Babino Polje, Blato). Therefore, in 2016, accommodation capacities reached 2,285 beds, twice as much as in 1986 , and coastal settlements (48\%) outnumbered the Park (41\%) in terms of beds (Tab. 1). The rather unfavourable structure of beds $(15.1 \%$ in a hotel, $13.7 \%$ in camps, and $71.2 \%$ in private households) generates very low net occupancy (51.5 days) (CBS, 2017). In 2018, there were 247 registered private owners and small businesses that offered rooms and apartments for rent (Mljet Tourist Board, 2019). Tourist arrivals $(25,788)$ and overnight stays $(117,646)$ are also significantly higher than before the War, with a growing share among coastal settlements (37\% and $42 \%)$. Tourism is mostly oriented towards international tourist markets ( $85 \%$ of overnight stays), led by Slovenia (14\%), Germany (11\%), France (8\%), and the UK (8\%) (CBS, 2017). The rather short average stay (4.6 days) reflects dominant coastal and nature-based tourism in conditions of an underdeveloped tourism supply and trends of shorter holidays on tourist markets.

\section{Can tourism revitalise the population of Mljet?}

A positive answer to this question is often given without prior in-depth analysis and consideration of the complex demographic and socio-economic processes within the population. This section aims to give an insight into multi-factored demographic processes and how much tourism has contributed to them. The analysis is based on total population change, net migration, share of migrants, and age composition in the 1961-2011 period.

The total population of Mljet (1,088 in 2011) is very low compared to other Croatian and Mediterranean islands of similar size and makes up less than $1 \%$ of the population of southern Dalmatia (Tab. 2). In the past, the island was isolated from major population cores and almost all of its people lived in small old rural settlements in the island's interior, and worked in agriculture (e.g. Babino Polje, Blato, Goveđari, Korita, Maranovići, 
Tab. 2 Changes in the population of Mljet by groups of settlements in the 196I-2011 period

\begin{tabular}{ccccccccc} 
& \multicolumn{3}{c}{ Population } & \multicolumn{5}{c}{ Index of total population change } \\
\cline { 2 - 9 } & Mljet & $\begin{array}{c}\text { Mljet } \\
\text { National } \\
\text { Park }\end{array}$ & Coastal & Interior & Mljet & $\begin{array}{c}\text { Mljet } \\
\text { National } \\
\text { Park }\end{array}$ & Coastal & Interior \\
\hline 1961 & 1,963 & 381 & 103 & 1,479 & - & - & - & - \\
\hline 1971 & 1,638 & 335 & 92 & 1,211 & 83.4 & 87.9 & 89.3 & 81.9 \\
\hline 1981 & 1,395 & 315 & 118 & 962 & 85.2 & 94.0 & 128.3 & 79.4 \\
\hline 1991 & 1,237 & 352 & 182 & 703 & 88.7 & 111.7 & 154.2 & 73.1 \\
\hline 2001 & 1,111 & 317 & 231 & 563 & 89.8 & 90.1 & 126.9 & 80.1 \\
\hline 2011 & 1,088 & 316 & 334 & 438 & 97.9 & 99.7 & 144.6 & 77.8 \\
\hline & & Index 1991/1961 & & 63.0 & 92.4 & 176.7 & 47.5 \\
\hline
\end{tabular}

Sources: FBS (1965; 1972); RBS (1983); CBS (1994; 2003; 2013)

Prožura). New coastal settlements took shape mostly in the $20^{\text {th }}$ century (particularly after World War II) around former warehouses and storage buildings in protected bays, due to tourism development (e.g. in Kozarica, Okuklje, Polače, Pomena, Prožurska Luka, Ropa, Saplunara) (Šulc, 2016). The only older coastal settlement is Sobra, which is the island's main port. Today, none of the island's settlements have more than 500 inhabitants; furthermore, the largest is the central settlement Babino Polje with 270 inhabitants; 7 have a population of 100 to 200, and 6 have less than 100 (Fig. 1).

The present settlement structure is largely result of population change in the 1961-2011 period. In 1961, before the most intensive tourism development took place, the island had a population of 1,963 (FBS, 1965). Most of them worked in traditional labour-intensive agriculture, and the island was marked by agricultural overpopulation. In the 196os, there was a mass exodus from agriculture and the island, as people left for work in Yugoslavia's blossoming industrial centres (Stražičić, 1969; Šulc and Valjak, 2012). As tourism on the island was in its infancy, it could not absorb the entire workforce (Šulc and Valjak, 2012) and other economic activities were almost non-existant.

The younger population used to leave the island due to the poor job market and also because of social opportunities offered by life in cities. Hence, in the 1961-1971 period, 321 more people left the island than moved 


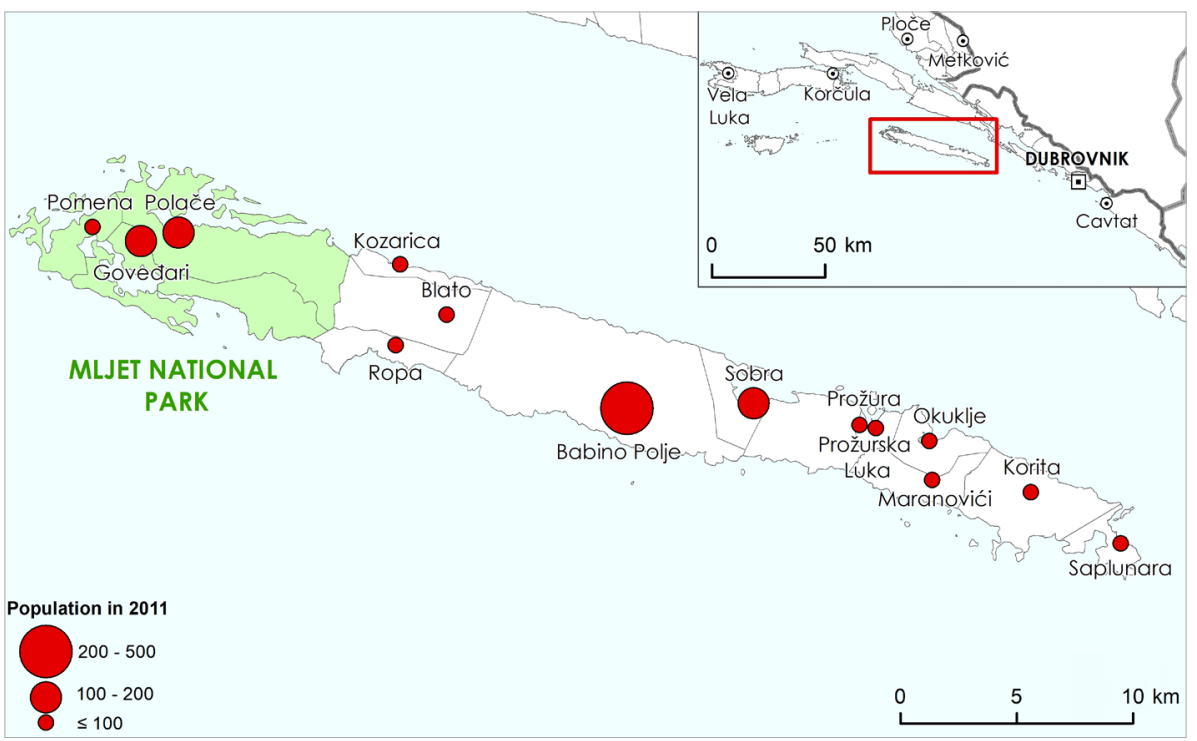

Fig. I Settlements on the island Mljet by population in $201 \mathrm{I}$

Sources: CBS (2013); CGA (2016)

to it, representing one-sixth of the population in 1961, and generating negative natural increase and a total depopulation of $14.8 \%$. As expected, interior rural settlements were the most affected by out-migration, but settlements in Mljet National Park were almost equally hit.

In the 1971-1981 and 1981-1991 periods, the population of the island continued to decrease with a lower intensity (by $14.8 \%$ and $11.3 \%$ ), and a declining rate of out-migration (Tab. 2). Moderate growth in tourism in both periods might be responsible for lower out-migration (Tab. 3), however, it is also inevitably related to the exhausted potential migrant contingent, i.e. those who wanted to leave the island had already left (See: Nejašmić, 1999; 2013). In the meantime, highly negative natural increase became main force of depopulation, due to previous selective out-migration that resulted in a disrupted age-sex composition.

On the other hand, instead of migration from the island, a part of the population moved from interior to the settlements in the Park and the coast, most probably due to tourism (renting accommodation, restaurants, tourism services in the Park, etc.) (Tab. 3). The island still could not manage to pull more people from the mainland that would stay there permanently, however, as the economic structure in most island regions was far simpler than on the mainland, and highly seasonal tourism usually did not offer year-round employment (Šulc, 2016). 
Tab. 3 Total population change (TPC), natural increase (NI), and net migration (NM) on Mljet by groups of settlements in the 196I-201 period

\begin{tabular}{|c|c|c|c|c|c|c|c|c|c|c|c|c|}
\hline \multirow{2}{*}{ Period } & \multicolumn{3}{|c|}{ Mljet } & \multicolumn{3}{|c|}{$\begin{array}{c}\text { Mljet National } \\
\text { Park }\end{array}$} & \multicolumn{3}{|c|}{$\begin{array}{c}\text { Coastal } \\
\text { settlements }\end{array}$} & \multicolumn{3}{|c|}{$\begin{array}{l}\text { Interior settle- } \\
\text { ments }\end{array}$} \\
\hline & TPC & NI & NM & $\mathrm{TPC}$ & $\mathrm{NI}$ & NM & $\mathrm{TPC}$ & NI & NM & $\mathrm{TPC}$ & NI & NM \\
\hline $1961-1971$ & -325 & -4 & -321 & -46 & 3 & -49 & -11 & -4 & -7 & -268 & -3 & -265 \\
\hline $1971-1981$ & -243 & -124 & -119 & -20 & -25 & 5 & 26 & -1 & 27 & -249 & -98 & -151 \\
\hline $1981-1991$ & -158 & -121 & -37 & 37 & 8 & 29 & 64 & -6 & 70 & -259 & -123 & -136 \\
\hline $1991-2001$ & -126 & -123 & -3 & -35 & -22 & -13 & 49 & 2 & 47 & -140 & -103 & -37 \\
\hline $2001-2011$ & -23 & -128 & 105 & -1 & -26 & 25 & 103 & -9 & 112 & -125 & -93 & -32 \\
\hline $1961-2011$ & -875 & -500 & -375 & -65 & -62 & -3 & 231 & -18 & 249 & -1041 & -420 & -621 \\
\hline
\end{tabular}

Sources: FBS (1965; 1972); RBS (1983); CBS (1965-2012; 1994; 2003; 2013)

Depopulation continued in the 1991-2011 period, mostly due to highly negative natural increase, resulting in 1,088 inhabitants in 2011 (Tab. 2). Net migration almost reached zero change in the 1991-2001 period, despite the War and crisis in tourism, while the 2001-2011 period was even characterised by positive net migration. Lower out-migration might be associated with the fact that some of the younger population chose to return to the island after they finished their education, due to better employment opportunities related to tourism and the Park. In-migration is mostly motivated by private reasons (e.g. marriage, family) and comprises a contingent of former second home owners that move to the island permanently (seasonally or year-round).

Depopulation is indeed the main demographic process on Mljet. From 1961 to 2011 the island lost $44.6 \%$ of its population, out of which $57 \%$ was by negative natural increase and $43 \%$ by negative net migration (Tab. 2 and 3 ). Along with Lastovo, it represents the largest population loss of all southern Dalmatian areas (e.g. Pelješac lost $17 \%$ of its population, Korčula $14 \%$, Konavle $2 \%$ ), while the population in southern Dalmatia as a whole increased by $23 \%$ (See: Šulc, 2016).

In the same time, the island has experienced a strong redistribution of its population. In $1961,75 \%$ of people lived in the interior of the island where the main agricultural areas are located, $20 \%$ lived in the Park, while only $5 \%$ lived on the coast. In 2011, interior settlements had only $40 \%$ of the population, the Park $29 \%$, while the share in coastal settlements had reached 
31\% (Tab. 2). What caused such a remarkable change? Interior settlements lost two-thirds of their population due to complete deagrarisation, which was not substituted by other economic activities. Having no working opportunities, the younger population was forced to leave and some of them saw tourism in coastal settlements as a potential source of income (Šulc and Valjak, 2012).

Hence, the population in coastal settlements increased by over threefold. Apart from Sobra, these small settlements developed from small agglomerations that consisted of storage buildings and warehouses for boats, owned by residents of interior settlements. Tourism development, starting in the 1970s, encouraged the transformation of existing objects and the construction of new ones as rental accommodation for tourists. This was perhaps sufficient to keep more of the local population on the island (Šulc and Valjak, 2012), but it was certainly not enough to attract potential migrants from the mainland. During the same period, the population of the Park decreased by $18 \%$, due to less intensive in-migration, associated with limited building permits, which, on the other hand, spared that area from over-construction (Šulc and Valjak, 2012). Despite its role as the tourist centre of the island, many who work in the Park choose to live in other parts of the island (Šulc and Valjak, 2012).

The analysed processes show that tourism did not manage to revitalise the population, but it contributed to divergent population development in the interior and on the coast, as well as in settlements within the Park. Another issue is the small size of the settlements, which generally lack an economically active population and initiatives, limiting tourism to the simple "sun and sea" paradigm, i.e. renting accommodation in households, and does not enable the full potential of the island to be realised.

The analysed spatial mobility is visible in the composition of the population by migration features in 2011. Around $54.5 \%$ of the population moved to their present place of residence (i.e. they did not always live there), which is above the regional average (49.2\%), and confirms the rather vivid documented migration in the recent period (CBS, 2013). Furthermore, $34.4 \% \mathrm{mi}-$ grated from another place on the island, as a part of the recent population redistribution. The share of migrants from the rest of Dubrovnik-Neretva County is equally high (32.9\%), comprising former islanders that had moved to Dubrovnik and returned to the island to retire, as well as their children, who see tourism as a source of income (CBS, 2013; Šulc, 2016). The lower share of in-migrants from other Croatian regions (15.5\%) and other coun- 
tries (17.2\% - half of them from Bosnia and Herzegovina) shows that extensive tourism management does not pull in people from distant regions effectively (CBS, 2013).

\section{Age composition}

Tourism impact on the population is the best visible in age composition, which is a reflection of past and present population change. In 1961, the population of Mljet was affected by ageing, with $\mathbf{1 2 . 3 \%}$ elderly population, and age index of 48.4, and an average age of 34.5 years (Tab. 4). It was not much worse than the average of southern Dalmatia (10.3\% of elderly, age index of 38.6 and average age of 32.7) (Šulc, 2016). Small differences among regions reflected lower intensity of migration with a high orientation towards agriculture, which had been keeping younger population in the region until this point.

Intensive age and sex selective out-migration from Mljet and subsequent natural increase resulted in the oldest population in southern Dalmatia in 1991, visible in share (28.8\%) of elderly population, an age index of 183.8 , and a very high average age of 45.4 (Tab. 4 ). Unlike 30 years earlier, the island's population was much older than the regional average that was $12.8 \%$ elderly people, with an age index of 61.8 , and an average age of 36.o years (Šulc, 2016). Therefore, we cannot confirm that extensive tourism development in the socialist period contributed to slower ageing on Mljet.

Rapid population ageing continued after the War and did not show any signs of slowing. In 2011, Mljet had the oldest population in southern Dalmatia, with a share of elderly population 2.5 times greater than young population (28.2\% to $11.1 \%)$, and extremely unfavourable indicators-an age index of 253.7, old age coefficient of 28.2, and average age of 47.0 years. The population of southern Dalmatia was less aged, with $17.8 \%$ elderly population, an age index of 109.7, 27 elderly to 100 adults, and an average age of 41 years (Šulc, 2016).

Even intensified (but still low) levels of tourism development and positive net migration in the recent period did not manage to slow decades of demographic momentum. The ageing population is now under the influence of demographic inertia (particularly due to the disrupted age-sex composition and negative natural increase) (See: Nejašmić, 2013), which can be changed only with intensive in-migration. In particular, there is negative ageing of the working contingent that generates economic development potential and new initiatives. These processes correspond to the 
Tab. 4 Indicators of age composition on Mljet in 196I, 1991, and 2011, by groups of settlements

\begin{tabular}{|c|c|c|c|c|c|c|c|}
\hline & Year & $\begin{array}{c}\text { Young } \\
\text { (o-14 } \\
\text { years) (\%) }\end{array}$ & $\begin{array}{c}\text { Adults } \\
(15-64 \\
\text { years) }(\%)\end{array}$ & $\begin{array}{c}\text { Elderly } \\
(65+ \\
\text { years })(\%)\end{array}$ & Age index & $\begin{array}{c}\text { Old age } \\
\text { depen- } \\
\text { dency } \\
\text { ratio }\end{array}$ & $\begin{array}{c}\text { Average } \\
\text { age }\end{array}$ \\
\hline \multirow{3}{*}{ Mljet } & 1961 & 25.3 & 62.4 & 12.3 & 48.4 & 19.6 & 34.5 \\
\hline & 1991 & 15.3 & 56.7 & 28.0 & 183.8 & 49.4 & 45.2 \\
\hline & 2011 & 11.1 & 60.7 & 28.2 & 253.7 & 46.5 & 47.0 \\
\hline \multirow{2}{*}{$\begin{array}{l}\text { Mljet } \\
\text { National Park }\end{array}$} & 1991 & 22.2 & 58.5 & 19.3 & 87.0 & 33.0 & 38.6 \\
\hline & 2011 & 12.0 & 66.1 & 21.8 & 181.6 & 33.0 & 44.0 \\
\hline \multirow{2}{*}{$\begin{array}{l}\text { Coastal } \\
\text { settlements }\end{array}$} & 1991 & 19.2 & 63.8 & 16.9 & 88.2 & 26.5 & 40.6 \\
\hline & 2011 & 13.5 & 64.1 & 22.5 & 166.7 & 35.0 & 44.0 \\
\hline \multirow{2}{*}{$\begin{array}{l}\text { Interior } \\
\text { settlements }\end{array}$} & 1991 & 10.7 & 54.0 & $35 \cdot 3$ & 328.4 & 65.3 & 49.6 \\
\hline & 2011 & 8.7 & 54.1 & 37.2 & 428.9 & 68.8 & 51.4 \\
\hline
\end{tabular}

\section{Sources: FBS (1965); CBS (1994; 2013)}

growing share of accommodation in households, which has turned tourism into the main complementary activity of the population instead of professionalising it.

However, differences among groups of settlements revealed that tourism might have had limited local impacts on population ageing, related to the previously analysed population redistribution. Coastal settlements and settlements in Mljet National Park have significantly younger populations than the island's average (but still aged), as a result of recent in-migration related to working opportunities in tourism and the Park, port, and other related economic activities. Depopulating interior settlements, as expected, have deeply aged populations and fewer opportunities for further demographic and socio-economic development (Tab. 4).

The analysis confirmed that direct connections between tourism development and demographic changes cannot be drawn, as both are influenced by many different factors (See: Zupanc et al., 200o). Effects of tourism on population revitalisation (or at least slower negative processes) have been limited even in regions with more intensive tourism development and cannot not be separated from wider socio-economic processes (Šulc, 2016). Besides being at least a decade late compared to the coast, tourism on Croatian islands developed in step with serious depopulation and pop- 
ulation ageing processes, which can be considered to be partially responsible for the less-developed tourism supply and difficulties in attracting newcomers from the mainland (Šulc, 2016). Higher levels of tourism development inevitably require a larger, adequately educated population, with high levels of initiative and interest in continual development of the tourism supply (Šulc, 2016).

\section{Socio-economic impacts of tourism}

The analysis of the socio-economic impact of tourism aims to determine to what level tourism influenced social and economic processes on the island, as well as how much the population is pressured by tourism. These processes were determined by investigating changes in educational composition, economic activity, and indicators of social pressure of tourism since 1961.

The educational composition of the population consists of "human capital" and it is one of the most important characteristics of the population in terms of potential economic development (Nejašmić, 1998; Nejašmić et al., 2009). In the 1961-2011 period, Mljet's population experienced large improvements in educational composition, but it always lagged behind the regional average. In 1961, the educational level was rather low-the education index was 0.0 , as $88 \%$ of the population had not even finished primary school, $7 \%$ had a primary school level education, $4 \%$ had a high school education, and only handful had a tertiary-level education (o.1\%) (Tab. 5).

Due to high orientation towards traditional agriculture, people used to only finish elementary school (or not attend school at all) and then start working in agriculture with their families. Bottom-up development of tourism was not something the one would expect. However, Mljet was not an exception at that time, as most of southern Dalmatia was still oriented towards agriculture and the regional average was just slightly higher (educational index was $0.3 ; 77.3 \%$ of the population had not finished elementary school, 9.5\% had a primary school level education, $11.4 \%$ had a secondary school level education, and 1.8\% had a tertiary-level education) (FBS, 1965).

In the following decades, the education composition of Mljet improved slowly, resulting in an educational index of only 1.9 in 1991, due to a persistently high share of people without any education (52\%) and only 5\% with tertiary-level education. Having no working opportunities outside agriculture, intensive out-migration in the 1960 s and 1970 s included the island's particularly educated inhabitants and resulted in the absence of an appropriate socio-economic transformation led by tourism, as was com- 
mon in other areas, and small improvements in the educational composition. Even moderate development of tourism in the Park in the 1980s had little effect on education level; its small improvements were part of general social development.

Tab. 5 Education composition of the Mljet population aged Is and above, in 196I, 199I, and 2011

\begin{tabular}{cccccc} 
Year & $\begin{array}{c}\text { Unfinished } \\
\text { primary } \\
\text { education }\end{array}$ & $\begin{array}{c}\text { Primary } \\
\text { education }\end{array}$ & $\begin{array}{c}\text { Secondary } \\
\text { education }\end{array}$ & $\begin{array}{c}\text { Tertiary } \\
\text { education }\end{array}$ & $\begin{array}{c}\text { Education } \\
\text { index }\end{array}$ \\
\hline 1961 & 88.4 & 7.2 & 4.3 & 0.1 & 0.0 \\
\hline 1991 & 52.2 & 22.7 & 20.3 & 4.9 & 1.9 \\
\hline 2011 & 11.7 & 27.3 & 49.4 & 11.6 & 49.0 \\
\hline
\end{tabular}

Sources: FBS (1965); CBS (1994; 2013)

Since the island had only an elementary school, those who had wanted to continue their education had to go to Dubrovnik or other cities and rarely returned to live on the island later, as there were no jobs for them outside of agriculture and poorly-developed tourism. On the other hand, developing a complex tourism supply, based on several types of tourism in as long a period as possible during the year, was not possible without a critical mass of highly-educated people. In the same period, southern Dalmatia experienced a strong economic transformation and tourism development, followed by large improvements in education levels. In 1991, the educational index reached 18.1 , with $25.1 \%$ of the population with no education, $32.5 \%$ with a primary-level education, $41.4 \%$ with a secondary-level education, and $11.0 \%$ with a tertiary-level education (CBS, 1994).

Data in 2011 revealed that the education level on Mljet has greatly improved (educational index 49.0), mostly due to the declining share of people with no education ( $12 \%$-in older age groups) and the growing share of people with secondary-level education (49\%) (Tab. 5). Despite stimulating higher education, increases in the share of well-educated people is still below expectations (12\%). Many young people decide not to study, since they find secondary-level education sufficient to work in tourism, while those who have studied rarely return due to the lack of jobs that require a university degree. Despite the improvements, Mljet still has one of the least-educated populations in southern Dalmatia, with an average educational in- 
dex of $128.6,8.1 \%$ with no education, $27.5 \%$ with primary-level education, $55.6 \%$ with secondary-level education, and $18.8 \%$ with tertiary-level education (CBS, 2013).

The analysis confirmed that it is not possible to draw a direct connection between tourism development and the level of education. Nevertheless, urban tourism areas with more educational institutions and larger job markets attract educated migrants and incentivise young people to stay in the area after their education. Concurrenly, rural tourism areas with lower education levels are limited to extensive tourism development that does not attract newcomers that are more educated.

\section{Tourism and transformation of economic activities}

Analysis of impacts of tourism on economic activity on Mljet was investigated using changes in the composition of the population by economic activity (active, with income, and dependent), in the composition of active population by sector of activity (primary, secondary, tertiary), share of agricultural workers in the total population, and labour force participation rate from 1961 to 2011.

The two main processes present on Mljet in the investigated period were the decrease in economic activity and transformation from agricultural to service economy (Tab. 6). In 1961, Mljet was an example of a typical agricultural region with $81 \%$ of its active population working in the primary sector. Agriculture was not specialised or professional and it usually represented a family businesses in which all members participated. Lower productivity was additionally influenced by small land parcels and agricultural overpopulation (the agricultural population was $69 \%$ of the total population) (FBS, 1965). The secondary sector employed 6\% of the population, mostly in trades/crafts and construction, while only $13 \%$ worked in services. The high share of active population (51\%) used to hide potential surpluses of workforce in agriculture, which is also visible in the high labour participation rate (81\%) (Tab. 6). Many elderly persons did not have a pension and still worked in agriculture, so only $2 \%$ of the population had a personal income.

In the 196os, Mljet was not much different from other rural regions that still had not experienced development of tourism and other non-agricultural activities, and where its relative remoteness prevented regular commuting to work in cities, which resulted in intensive out-migration. However, other parts of southern Dalmatia had already experienced a tran- 
sition to a service economy, stimulated by tourism development that was still limited to large tourist resorts, while industry had a transformative role only in some small communities ${ }^{3}$.

In the 1960s, Mljet experienced intensive deagrarisation followed by moderate out-migration, which was further intensified in the 1970s, due to slow and insufficient tourism development that still had the main transformative role, along with activities related to Mljet National Park (in 1971, the share of agricultural population was $27 \%$ and had fallen to $9 \%$ by 1981 ). By 1991, the socio-economic transformation of the island was finished, when the share of agricultural population reached its minimum of $5 \%$, which has persisted to the time of writing (CBS, 1994). Services became the predominant occupation for $82 \%$ of the active population, while $15 \%$ still worked in agriculture, and only $3 \%$ in the secondary sector (Tab. 6) ${ }^{4}$.

The population in the western part of the island mostly worked in services related to tourism and the Park, while in the eastern part of the island, port activities, transport, and administration employed more of the active population than tourism. Good agricultural resources in the central part of the island were still used for crop cultivation, as opposed to services in terms of work opportunities. However, these processes did not result in professionalisation of agriculture, rather in the abandonment of less fertile land and the spread of a depopulation landscape (See: Nejašmić, 1991). In the same period, the activity rate decreased to $34 \%$, accompanied by one of the lowest labour force participation rates in the region (58\%). Low activity was associated with the model of tourism, that relied on renting accommodation in households and did not enable year-round jobs, as well as with serious population ageing, which was visible in growing share of persons with income $(27 \%)^{5}$.

3 In 1961, southern Dalmatia had $41 \%$ active population, $6 \%$ had a personal income, and $53 \%$ were dependent, while the labour force participation rate was $63 \%$ (FBS, 1965). Primary sector workers were the largest group (47\%), followed by secondary (21\%), and services (32\%), while the share of agricultural population was $39 \%$ (FBS, 1965).

$4 \quad$ Mljet followed the patterns experienced throughout southern Dalmatia, which, in 1991 , had $7 \%$ of its working population in agriculture, $20 \%$ in the secondary sector, and $73 \%$ in services, while the share of agricultural population was only $5 \%$ (CBS, 1993).

5 In 1991, southern Dalmatia had 44\% active population, 15\% with personal income, and $41 \%$ were dependent, while the labour force participation rate was $64 \%$ (CBS, 1994). 
Tab. 6 Composition of the population of Mljet by economic activity and composition of the working population by the sector of activity in the 1961-201 period

\begin{tabular}{|c|c|c|c|c|c|c|c|}
\hline \multirow[b]{2}{*}{ Year } & \multicolumn{3}{|c|}{ Economic activity (\%) } & \multicolumn{3}{|c|}{ Sector of employed persons (\%) } & \multirow{2}{*}{$\begin{array}{l}\text { Labour } \\
\text { force par- } \\
\text { ticipation } \\
\text { rate }(\%)\end{array}$} \\
\hline & Active & $\begin{array}{l}\text { With } \\
\text { income }\end{array}$ & $\begin{array}{c}\text { Depen- } \\
\text { dent }\end{array}$ & Primary & Secondary & Tertiary & \\
\hline 1961 & 50.7 & 2.1 & 47.2 & 81.4 & 5.8 & 12.8 & 81.4 \\
\hline 1971 & 39.1 & 10.9 & 50.1 & 71.6 & 6.4 & 22.1 & 61.5 \\
\hline 1981 & 29.1 & 22.0 & 48.9 & - & - & - & 48.8 \\
\hline 1991 & $33 \cdot 9$ & 26.6 & 39.6 & 14.6 & 2.8 & 82.6 & 58.0 \\
\hline 2001 & 30.6 & 35.0 & $34 \cdot 4$ & 7.8 & 6.2 & 86.0 & 55.5 \\
\hline 2011 & 39.4 & 37.4 & 23.2 & $3 \cdot 3$ & 11.9 & 84.8 & 62.2 \\
\hline
\end{tabular}

Sources: FBS (1965; 1972; RBS (1983); CBS (1994; 2003)

The analysed processes continued on Mljet with lower intensity after the War and the recovery of tourism. The further decrease in agriculture (3\% in 2011) is associated with advanced population ageing and growing orientation towards tourism, which has all the characteristics of a monoculture ( $85 \%$ of the population worked in services in 2011) (Tab. 6). Southern Dalmatia, in contrast, has a more diversified composition of active population, due to its more complex economy-in 2011, $7 \%$ worked in the primary sector, $15 \%$ in the secondary sector, and $78 \%$ in services (CBS, 2013).

Mljet still belongs to the group of less developed regions with lower economic activity and fewer jobs, expressed depopulation and population ageing, lower educational levels and lack of initiatives for further development. In 2011, the island had the lowest share of active population (39\%) and one of the lowest labour force participation rates in southern Dalmatia $(62 \%)$, while the share of people with personal income was high $(37 \%)^{6}$. However, lower activity rates hide the level of real employment, as a significant part of the population with income work occasionally or seasonally in tourism.

The analysis revealed that in the period of socio-economic transformation of the island, tourism absorbed a part of the population that had left agriculture and that would otherwise have left the island. However, as is the case with educational level, it is not possible to draw a direct connec-

6 In 2011, the activity rate in southern Dalmatia was $51 \%$, the labour participation rate was $65 \%$, and the share of persons with income was $28 \%$ (CBS, 2013). 
tion between the level of tourism development and changes in the level of economic activity and its structure. The relation between tourism development and economic activity shows certain profiling only when a region reaches higher level of tourism development that starts to dominate among economic activities.

\section{Social pressure of tourism}

Besides contributing to socio-economic development, tourism generates a certain pressure on the area and the community in which takes place. This section aims to evaluate the social pressure of tourism on Mljet using the tourism function index and tourism intensity.

Near beginning of the investigated period (in 1966), the tourism intensity score of 81.7 on Mljet could not be considered to be pressure at all; furthermore, it represented a desirable alternative to the dominant agriculture (Tab. 7). Contemporary southern Dalmatia records considerable pressure of tourism (353.7), generated mostly by the Dubrovnik Littoral, and accompanied by a few small areas with high pressure (Mljet National Park, the bearer of tourism on the island, reached 420.7 arrivals per 100 inhabitants) (FBS, 1965; 1972; RBS, 1967).

Pressure of tourism in the late 1960 s and in the 1970 gradually increased along with the opening of new accommodation units (particularly a hotel in Pomena) and growth of tourism, and reached 221.4 arrivals and 68.2 beds per 100 inhabitants in 1976 (Tab. 7). Tourism was still limited to the Park, which had one hotel, one camp, and a few accommodation units in private households generating very high pressure (1,018.8 arrivals and 300.6 beds per 100 inhabitants). Outside the Park, only Sobra recorded modest tourism development. However, it is important to note that the island's small population is partially responsible for the high pressure of tourism in the whole period, as it has to handle a relatively large tourism supply and demand.

The island reached peak pressure in 1986 with 793.3 arrivals and 89.7 beds per 100 inhabitants, which was not much different from the regional average (846.6 and 61.1, respectively) (RBS, 1982; 1987; CBS, 1994). However, Mljet National Park recorded one of the highest pressures in southern Dalmatia $(3,422.9$ arrivals and 322.0 beds per 100 inhabitants), which was heavily contributed to by day-trippers visitors from Pelješac, Korčula, and Dubrovnik. 
Tab. 7 Indicators of social pressure of tourism on Mljet in the 1966-2016 period, by groups of settlements

\begin{tabular}{ccccccccc} 
& \multicolumn{3}{c}{ Tourism function index } & \multicolumn{5}{c}{ Tourism intensity } \\
\cline { 2 - 9 } Year & Mljet & $\begin{array}{c}\text { Mljet } \\
\text { National } \\
\text { Park }\end{array}$ & Coastal & Interior & Mljet & $\begin{array}{c}\text { Mljet } \\
\text { National } \\
\text { Park }\end{array}$ & Coastal & Interior \\
\hline 1966 & - & - & - & - & 81.7 & 420.7 & 0.0 & 0.0 \\
\hline 1971 & - & - & - & - & 134.4 & 675.7 & 0.0 & 0.0 \\
\hline 1976 & 68.2 & 300.6 & 54.3 & 0.0 & 221.4 & $1,018.8$ & 189.1 & 3.3 \\
\hline 1981 & 69.8 & 266.3 & 63.6 & 6.2 & 386.4 & $1,713.5$ & 162.9 & 11.0 \\
\hline 1986 & 89.7 & 322.0 & 71.3 & 0.0 & 793.3 & $3,422.9$ & 241.5 & 0.0 \\
\hline 1991 & 35.2 & 123.9 & 0.0 & 0.0 & 55.4 & 218.6 & 0.0 & 0.0 \\
\hline 1996 & 60.4 & 212.0 & 0.0 & 0.0 & 274.4 & 964.2 & 0.0 & 0.0 \\
\hline 2001 & 113.4 & 212.9 & 51.9 & 82.6 & 704.5 & $2,073.2$ & 147.2 & 163.0 \\
\hline 2006 & 147.4 & 246.8 & 228.3 & 39.0 & $1,323.8$ & $3,464.0$ & $1,000.0$ & 251.5 \\
\hline 2011 & 138.5 & 223.7 & 171.9 & 51.6 & $1,339.5$ & $3,176.9$ & $1,122.8$ & 299.9 \\
\hline 2016 & 212.3 & 298.3 & 285.9 & 64.4 & $2,370.2$ & $4,794.6$ & $2,844.3$ & 259.6 \\
\hline
\end{tabular}

Sources: FBS (1965; 1972); RBS (1967; 1972; 1977; 1982; 1983; 1987); CBS (1992; 1994; 1997; 2002; 2003; 2007b; 2012; 2013; 2017)

Rather high pressure of tourism in some small tourist resorts with more complex accommodation structures (e.g. Mljet National Park) represented one of many reasons behind the tourism decline that followed. Tourism in Croatia in the late 198 os suffered from various internal weaknesses and external factors, particularly shifting tourist preferences and stronger competition from tourism destinations in other countries. On the internal side, tourism arrivals and overnight stays exceeded the capacities of local communities, infrastructure, and workforce in resorts, which started to cause negative effects in the summer season and damaged the tourism experience. Therefore, after 1986, tourism entered a stage of decline (See: Šulc, 2016; 2017); accompanied by the War, this prevented tourists from visiting Croatia. Tourism intensity decreased more rapidly than the tourism function index, indicating that accommodation capacities were still available but visitors stopped coming.

Intensive recovery of tourism in the late 1990s again increased the pressure on the island, accompanied by growing pressure on coastal and 
interior settlements outside the Park, generated by the diffusion of tourism. In 2001, tourism intensity almost reached the pre-war level (704.5), while the tourism function index largely exceeded the pre-war maximum (113.4). The growing pressure on Mljet was much more rapid than in the broader area of southern Dalmatia (458.6 and 44.0, respectively), but in both areas its intensification was associated with the increase of accommodation capacity in private households (CBS, 2002; 2003).

Instead of medium and large hotels, whose location and design were carefully planned to fit the cultural landscape, numerous new private objects, often unplanned, illegal, without required permissions, were built outside construction areas of settlements and not adjusted to the environment, which led to the spread of urbanised areas in the most attractive coastal areas. This blocked these areas from being used for other, more productive (tourism) functions. At the same time, the classic "sun and sea" tourism product remained the core of the tourism supply, generating growing pressure of tourism on infrastructure, settlements, environment, and local communities in the short summer season.

Despite the analysed processes, the pressure of tourism on Mljet increased continuously in the 2000 s and 2010 s and exceeded the pre-war maximums by 2 or 3 times. With $2,370.2$ arrivals and 212.3 beds per 100 inhabitants in 2016, Mljet became one of the most pressured areas in southern Dalmatia, largely exceeding regional averages $(1,302.8$ and 69.8 , respectively) (CBS, 2003; 2013; 2017). It is important to note that, apart from registered tourism, an additional $30 \%$ of tourist arrivals and overnight stays goes unregistered (according to tourism stakeholders) (Šulc, 2016). Although it may seem that spatial diffusion of tourism has distributed its pressure equally throughout the island, the high level of pressure is still unacceptable for an area with preserved natural environment, and particularly for a national park, which requires a strict and sustainable development regime for tourism.

The pressure is particularly high in very small coastal settlements, with low levels accommodation and inhabitants, which experience rather intensive private tourism construction, often lacking basic communal and tourism infrastructure. However, it is important to stress that high pressure is often the consequence of small absolute figures and cannot be compared to large tourist resorts, meaning that this has to be taken with caution in the analysis. It is indicative that in 9 out of 14 settlements the number of tourist beds exceeds the population, e.g. in Pomena by 11 times over and 
in Saplunara by sixfold. Apart from registered tourists, the island's coastal settlements are additionally pressured by rather intensive nautical tourism, which is not officially registered. However, due to the low level of development of other economic activities, the local population does not perceive tourism as a pressure or a burden and welcomes its further development. It is important to emphasise that the main problem is not the number of beds themselves but the fact that the peak development of tourism on Mljet is limited to "sun and sea", which fails to fully realise the island's potential, and causes an intensive, often deteriorating, physical transformation of tourism areas.

\section{Conclusion}

All the goals defined in the chapter's introduction have been fulfilled and a deeper insight into the relationship between tourism and demographic and socio-economic processes in protected areas in the Croatian Littoral was provided. It was confirmed that it is not possible to draw a direct link between tourism development and demographic changes because both processes are influenced by various factors (See: Zupanc et al., 2000). As in other remote and/or rural island or peninsular areas, development of tourism occurred under the conditions of a disrupted age-sex composition (See: Nejašmić, 1998; 1999; 2013), which was partially responsible for the lower level/quality of the tourism supply and did not have the power to pull new migrants from the mainland (Šulc, 2016). Nevertheless, even extensively developed tourism gave part of the local population the opportunity to earn more for a living and managed to keep them on the island. Therefore, tourism can be considered to be the most important factor of the socio-economic transformation of the island, particularly in terms of work and economic activity.

The analysis also revealed very high social pressure of tourism on a small population, much higher than in some developed tourism areas (e.g. Dubrovnik). Although the local population welcomes further development due to its beneficial economic effects, the current pressure on the environment is great, and this makes the local economy extremely sensitive to any oscillations in the tourism market. As the pressure is the highest in the summer and generated largely by tourism in private households with a low occupancy rate, future tourism development should focus on the development of small hotels and the creation of a more complex tourism supply, aimed to prolong the tourist season. 
Experiences of developed tourism destinations in the Mediterranean area confirmed that, in cases of similar accommodation capacities, destinations with more beds in hotels have much higher numbers of tourist arrivals and overnight stays than those with high shares of accomodation in private households. Furthermore, as Mljet National Park is the most pressured area, priority should be given to preserving the environment and developing non-invasive tourism activities that would valorise it. If the paradigm of tourism development on Mljet remains the same, the island could face degradation of its natural environment and cultural landscape, as well as lack of sufficient workforce and the need to import a larger number of workers from the mainland.

\section{References}

Andriotis, K., 2006: Hosts, Guests and Politics: Coastal Resorts Morphological Change, Annals of Tourism Research 33 (4), 1079-1098, DOI: 10.1016/j. annals.2006.04.003.

Black, A., 1996: Negotiating the tourist gaze: The example of Malta, in: Coping with Tourists: European Reactions to Mass Tourism (ed. Boissevain, J.), Berghahn Books, Oxford, 112-142.

Boissevain, J., Theuma, N., 1998: Contested space. Planners, tourists, developers and environmentalists in Malta, in: Anthropological Perspectives on Local Development (eds. Abram, S., Waldren, J.), Routledge, London, 96-119.

Bramwell, B., 2003: Mass Tourism, Diversification and Sustainability in Southern Europe's Coastal Regions, in: Coastal Mass Tourism: Diversification and Sustainable Development in Southern Europe (ed. Bramwell, B.):, Channel View Publications, Clevedon, 1-31.

Butler, R., 1980: The Concept of a Tourist Area Cycle of Evolution: Implications for Management of Resources, Canadian Geographer 24, 5-12.

Chapman, A., Speake, J., 2011: Regeneration in a mass-tourism resort: The changing fortunes of Bugibba, Malta, Tourism Management 32 (3), 482491, DOI: 10.1016/j.tourman.2010.03.016.

Doxey, G., 1975: A causation theory of visitor-resident irritants: methodology and research inferences in the impact of tourism, in: Sixth annual conference proceedings of the Travel Research Association, San Diego, 195-198. 
Faričić, J., Graovac, V., Čuka, A., 2010: Croatian Small Islands - Residential and/or Leisure Area, Geoadria 15 (1), 145-185, DOI: doi.org/10.15291/ geoadria.548.

Garay, L., Cànoves, G., 2011: Life Cycles, Stages and Tourism History. The Catalonia (Spain) Experience, Annals of Tourism Research 38 (2), 651-671., DOI: 10.1016/j.annals.2010.12.006.

Ioannides, D., 2001: The dynamics and effects of tourism evolution in Cyprus, in: Mediterranean Tourism: Facets of socioeconomic development and cultural change (eds. Apostolopoulos, Y. et. al.), Routledge, London - New York, 129-145.

Lajić, I., 2006: Kvarnerski otoci - demografski razvoj i povijesne mijene, Institut za migracije i narodnosti, Zagreb.

Lajić, I., Mišetić, R., 2006: Otočni logaritam. Aktualno stanje i suvremeni demografski procesi na jadranskim otocima, Institut za migracije i narodnosti, Ministarstvo mora, turizma, prometa i razvitka, Zagreb.

Nejašmić, I., 1991: Depopulacija u Hrvatskoj: korijeni, stanje, izgledi, Globus nakladni zavod, Zagreb.

Nejašmić, I., 1992: Promjene u dobno-spolnom sastavu stanovništva istočnojadranskog otočja, Acta Geographica Croatica 27, 15-34.

Nejašmić, I., 1998: Croatian islands - the role of demographic features in tourism development, Croatian Geographical Bulletin 6o, 17-30.

Nejašmić, I., 1999: Uloga turizma u diferenciranom demografskom razvitku otočnih naselja: primjer srednjodalmatinskog otočja, Croatian Geographical Bulletin 69, 37-52.

Nejašmić, I., 2005: Demogeografija: stanovništvo u prostornim odnosima i procesima, Školska knjiga, Zagreb.

Nejašmić, I., 2013: Demografsko starenje na hrvatskim otocima, Migracijske i etničke teme 29 (2), 141-168, DOI: 10.11567/met.29.2.2.

Nejašmić, I., Mišetić, R., 2006: Population of the Vis Island, Geoadria 11 (2), 283-309, DOI: 10.15291/geoadria.111.

Nejašmić, I., Toskić, A., Mišetić, R., 2009: Demografski resursi Republike Hrvatske: Sintetični pokazatelji za županije, gradove i općine, Hrvatsko geografsko društvo, Zagreb.

Pulina, M., Biagi, B., 2006: Regional public policy and tourism life cycle: the case of Sardinia, 46th Congress of the European Regional Science Association University of Thessaly, Volos. 
Starc, N., 2001: Managing island development: the Croatian case, Sociologija sela $39(1-4), 15-36$.

Stražičić, N., 1969: Otok Mljet. Regionalna izdvojenost i socijalno-geografski problemi, Acta eographica Croatica 8, 119-159.

Šubić, N., 1995: Turizam Mljeta jučer i sutra, in: Mljet: zbornik radova sa simpozija Prirodne značajke i društvena valorizacija otoka Mljeta (eds. Durbešić, P, Benović, A.), 691-698.

Šulc, I., 2016: Models of Tourism Development in South Dalmatia, Croatia, Doctoral Thesis, University of Zagreb, Faculty of Science, Zagreb (in Croatian).

Šulc, I., 2017: Distorted life cycle on post-socialist Adriatic islands: Using the example of Mljet, Croatia, Acta Turistica 29 (1), 33-73, DOI: 10.22598/ at/2017.29.1.33.

Šulc, I., 2019: Environmental Impacts of Tourism on the Eastern Adriatic Coast - The Case of South Dalmatia, Croatia, in: Atti del XXXII Congresso Geografico Italiano, 2777-2789.

Šulc, I., Valjak, V., 2012: Protected Areas as a Factor in Sustainable Development of the Croatian Islands - the Example of Mljet Island, Croatian Geographical Bulletin 74 (1), 161-185 (in Croatian), DOI: 10.21861/ HGG.2012.74.01.09.

Šulc, I., Zlatić, M., 2014: Demographic Changes on Small Adriatic Islands: The Case Study of Ilovik, Croatia, Sociology and Space 52 (1), 3-22, DOI: 10.5673/sip.52.1.1.

Zhong, L., Deng, J., Xiang, B., 2008: Tourism development and tourism area life-cycle model: A case study of Zhangjiajie National Forest Park, China, Tourism Management 29 (5), 841-856, DOI: 10.1016/j.tourman.2007.10.002.

Zupanc, I., Opačić, V. T., Nejašmić, I., 200o: Utjecaj turizma na demografska kretanja hrvatskih otoka, Acta Geographica Croatica 35, 133-146.

\section{Sources}

Croatian Bureau of Statistics (CBS), 1965-2012: Livebirths and Deaths 1964-2011, by settlements, CD-ROM, Zagreb.

Croatian Bureau of Statistics (CBS), 1992: Tourism Turnover in Seaside Municipalities in 1991, Statistical Report, Zagreb.

Croatian Bureau of Statistics (CBS), 1994: Census of Population, Households and Dwellings in 1991, Documentation 881-888, Zagreb. 
Croatian Bureau of Statistics (CBS), 1997: Tourism Turnover in Seaside Towns and Municipalities in 1996, Statistical Report, Zagreb.

Croatian Bureau of Statistics (CBS), 2002: Tourism Turnover in Seaside Towns and Municipalities in 2001, Statistical Report, Zagreb.

Croatian Bureau of Statistics (CBS), 2003: Census of Population, Households and Dwellings $31^{\text {st }}$ March 20o1, CD-ROM, Zagreb.

Croatian Bureau of Statistics (CBS), 2007a: Statistical Classification of Economic Activities, http://www.ips-servis.hr/files/warehouse/2014/ nkd2007.pdf (08. 09. 2019)

Croatian Bureau of Statistics (CBS), 2007b: Tourism in Seaside Towns and Municipalities in 2006, Statistical Report, Zagreb.

Croatian Bureau of Statistics (CBS), 2012: Tourism in 2011, Internal Database by Settlements, Zagreb.

Croatian Bureau of Statistics (CBS), 2013: Census of Population, Households and Dwellings in 2011, www.dzs.hr (08. 09. 2019)

Croatian Bureau of Statistics (CBS), 2017: Tourism in Seaside Towns and Municipalities in 2016, Statistical Report, Zagreb.

Croatian Geodetic Administry (CGA), 2016: Central Registry of Spatial Units in the Republic of Croatia, GIS shapefiles.

Federal Bureau of Statistics (FBS), 1965: Census of Population in 1961, Book XIXV, Belgrade.

Federal Bureau of Statistics (FBS), 1972: Census of Population and Dwellings in 1971, Belgrade.

Mljet Tourist Board, 2019: Accommodation, http://www.mljet. $\mathrm{hr} /$ ? $=$ hr\&ispis $=$ staticna\&id $=5$ (09. 09. 2019)

Pansion Jezero, 2015: Tko smo mi?, http://free-zg.t-com.hr/tpudic/Hrv/kucahist. htm (o8. 12. 2015)

Republic Bureau of Statistics (RBS), 1967: Tourism Turnover in Seaside Resorts I-XII 1966, Documentation, Zagreb.

Republic Bureau of Statistics (RBS), 1972: Tourism Turnover in Seaside Resorts in 1971, Documentation, Zagreb.

Republic Bureau of Statistics (RBS), 1977: Tourism Turnover in Seaside Municipalities in 1976, Documentation, Zagreb.

Republic Bureau of Statistics (RBS), 1982: Tourism Turnover in Seaside Municipalities in 1981, Documentation, Zagreb. 
Republic Bureau of Statistics (RBS), 1983: Census of Population, Households and Dwellings $31^{\text {st }}$ March 1981, Zagreb.

Republic Bureau of Statistics (RBS), 1987: Tourism Turnover in Seaside Municipalities in 1986, Documentation, Zagreb. 